\title{
Pengembangan Media Big Book Terhadap Kemampuan Memprediksi Bacaan Cerita Siswa
}

\section{Sekolah Dasar}

\section{${ }^{1}$ Rora Rizky Wandini, ${ }^{2}$ Nirwana Anas, ${ }^{3}$ Emeliya Sukma Dara Damanik, ${ }^{4}$ Melani Albar, ${ }^{5}$ Maya Rani Sinaga}

Universitas Islam Negeri Sumatera Utara Medan, Email:

${ }^{1}$ rorarizkiwandini@uinsu.ac.id,Universitas Islam Negeri Sumatera Utara

Medan, ${ }^{2}$ nirwanaanas@uinsu.ac.id,Universitas Islam Negeri Sumatera Utara

Medan, ${ }^{3}$ emeliyasukmadaradamanik@uinsu.ac.id,Universitas Islam Raden Rahmat

Malang, ${ }^{4}$ melani.albar@uniramalang.ac.id,Universitas Islam Negeri Sumatera

Utara Medan, ${ }^{5}$ mayaranisinaga@gmail.com

\begin{abstract}
Abstrak
Penelitian ini bertujuan mengetahui efektivitas pengembangan big book terhadap kemampuan mempredikksi bacaan cerita siswa kelas III di SD Muhamadiyah 28 Medan. Dari hasil analisis menggunakan uji Shapiro-Wilk, uji Wilcoxon,dan uji hipotesis Mann-Whitiney dengan taraf signifikasi $\propto=0.05$. Temuan dalam penelitian ini membuktikan bahwa pengembangan media big book terhadap kemampuan memprediksi bacaan cerita siswa tersebut dinyatakan layak dan dapat digunakan dilhat dari hasil validasi ahli isi dan ahli media dengan skor $76 \%$, media ini juga dinyatakan praktis dalam penggunaannya dilihat dari 14 kriteria dengan persentase $85,71 \%$ dan penggunaan media big book ini juga sangat efektif digunakan untuk meningkatkan kemampuan memprediksi bacaan cerita siswa kelas III di SD Muhamdiyah 28 Medan dengan persentase 92,6\% pada sampel dan 87,5\% pada guru pada taraf Asym Sig 0,001 < dari taraf signifikasi 0,05. Sebagai hasil akhir dilakukan uji hipotesis Mann-Whitney dengan hasil signifikasi 0,002 sehingga, berdasarkan kriteria pengambilan keputusan $\mathrm{H}_{0}$ ditolak dan $\mathrm{H}_{\mathrm{a}}$ diterima.
\end{abstract}

Kata Kunci :Pengembangan, Media, Big book, Memprediksi Bacaan cerita, Sekolah Dasar 


\section{PENDAHULUAN}

Pembelajaran merupakan suatu system yang disusun sedemikian rupa untuk mempengaruhi dan mendukung proses belajar siswa serta memuat suatu kegiatan yang sistematik, bersifat interaktif dan komunikatif antara guru ke siswa maupun sebaliknya, ${ }^{1}$ Pada prosesnya pembelajaran yang dirangkai guru untuk setiap pertemuannya memiliki capaian kompetensi yang berbeda. ${ }^{2}$ Capaian kompetensi tersebut dikatakan berhasil ditandai dengan perolehan pengetahuan, keterampilan, dan sikap positif pada diri individu sesuai dengan tujuan yang diharapkan. ${ }^{3}$ Salah satu factor penduduk dalam keberhasilan tersebut adalah penggunaan media pembelajaran. $^{4}$

Pengunaan media dalam pembelajaran juga perlu diperhatikan,terutama harus disesuaikan dengan materi yang akan diajarkan. Pemilihan media pembelajaran selain disesuaikan dengan materi juga harus memperhatikan tahap perkembangan anak seperti yang diungkapkan Piaget. ${ }^{5}$ Berdasarkan teori piaget tersebut untuk usia siswa sekolah dasar berada pada tahap operasional konkret, siswa tersebut berfikir logis, dan pada tahap ini Bahasa merupakan pondasi yang dapat membantunya dalam mencerna pembelajaran, bukan hanya itu Bahasa juga merupakan pondasi bagi perkembangan literasinya. ${ }^{6}$

Berdasarkan hasil observasi awal penggunaan buku paket yang menjadi sumber belajar utama kurang menarik siswa untuk focus dalam belajar serta banyaknya tulisan yang memenuhi sumber belajar yang dimaksud kurang mengasah perkembangan berfikir logis siswa, sehingga diperlukan suatu media pembelajaran yang sesuai untuk tahap perkembangan siswa kelas III sekolah dasar tersebut. Media pembelajaran yang dimaksudkan adalah Big Book.Big Book

\footnotetext{
${ }^{1}$ Lefudin, Belajar \& Pembelajaran, (Yogyakarta: Deepublish,2017) hlm.13.

${ }^{2}$ H.M Syakur, Pembelajaran Tematik Untuk Kelas Rendah, (Kudus: Maseifa Jendela Ilmu,2016) hlm.1

${ }^{3}$ Asep Kustiawan, Pengembangan Media Pembelajaran Anak Usia Dini, (Malang: Gunung Samudera,2016) hlm.9.

${ }^{4}$ Junaida dkk, Pembelajaran Bahasa Indonesia di MI/SD, (Medan: Perdana Publishing,2018), hlm.72.

${ }^{5}$ Sri Esti Wuryani Djiwandono, (2004), Psikologi Pendidikan, Jakarta: Grasindo, hlm.72.

${ }^{6}$ Nurul Hidayah,Pembelajaran Bahasa Indonesia di Perguruan Tinggi, (Yogyakarta: Garudhawaca,2016), hlm.2.
} 
merupakan buku cerita yang berkarakteristik khusus yang dibesarkan, baik teks maupun gambarnya, sehingga memungkinkan terjadi kegiatan membaca bersama antara guru dan siswa. ${ }^{7}$

Di Indonesia penelitian tentang Big Book ini telah banyak dilakukan seperti penelitian Nisfhi Syelviana dan Sri Hariani, ${ }^{8}$ Gunanti Setiyaningsih dan Amir Syamsuddin, ${ }^{9}$ Irma Rahmawati, ${ }^{10}$ Ivonne Hafidlatil Kiromi ,dkk, ${ }^{11}$ dari hasil penelitian mereka dapat disimpulkan bahwa Big Book digunakan sebagai media pembelajaran cukup efektif, dan kesemuanya terfokus pada kemampuan membaca siswa, namun dalam penelitian ini focus yang ingin dicapai merupakan kemampuan memprediksi isi bacaan atau cerita, dan fokus ini masih jarang yang menelitinya serta untuk daerah Medan penggunaan big book ini masih kurang popular ditelinga para guru sekolah dasar. Gaung penggunaan big book untuk sekolah di daerah Medan mulai disuarakan pada tahun 2109 lalu oleh Tanoto Foundation, namun masih sekolah-sekolah yang dipilih saja, belum menyeluruh. Maka, karena masih minimnya penggunaan Big Book ini di medan peneliti, diharapkan desain big book yang dikembangkan nantinya akan dapat memberi manfaat kepada siswa khususnya pada peningkatan kemampuan memprediksi bacaan serta dapat membantu guru dalam proses pembelajaran.

Kemampuan memprediksi bacaan sendiri sangat erat kaitannya dengan kemampuan dalam memahami bacaan. Jamaruddin menyatakan bahwa kecenderungan siswa yang tidak dapat memahami bacaan maka akan berdampak pada sulitnya siswa meraih prestasi ketika naik pada tingkat kelas yang lebih hlm.7.

${ }^{7}$ Solehuddin dkk, Pembaharuan Pendidikan TK, (Jakarta: Universitas Terbuka,2009)

${ }^{8}$ Nisfhi Syelviana dan Sri Hariani, Pengembangan Media Big Book dalam Pembelajaran Membaca Permulaan di Kelas I Sekolah Dasar,Surabaya: Jurnal PGSD Vol.07, No.01, diakses pada 16 Januari 2019.

${ }^{9}$ Gunanti Setiyaningsih dan Amir Syamsudin, Pengembangan Media Big Book Untuk Meningkatkan Kemampuan Literasi Anak Usia 5-6 Tahun, Yogyakarta: Jurnal Scholaria, Vol.9, No.1, diakes pada 16 Januari 2019.

${ }^{10}$ Irma Rahmawati, (2017), Pengembangan Media Big Book berbasis Keterampilan Membaca Peserta didik Kelas 1 Sekolah Dasar, Semarang: Artikel Seminar Nasional PGSD, diakses pada 16 Januari 2019.

${ }^{11}$ Ivonne Hafidlatil Kiromi dan Puji Yanti Fauziah, (2016), Pengembangan Media Big Book untuk Pembentukan Karakter Anak Usia Dini, Yogyakarta: Jurnal Pendidikan dan Pemberdayaan Masyarakat,Vol.3, No.1 diakses pada 18 Januari 2019. 
tinggi. Hal itu disebabkan semakin tinggi tingkatan kelasnya maka informasi yang diperoleh siswa semakin rumit pula.Nah, untuk menguatkan tingkat pemahaman membaca siswa maka pendekatan menghafal keseluruhan isi bacaan harus diterapkan. Berapa banyak siswa dalam satu kelas?, sulit rasanya bagi guru untuk mendapatkan feetback yang baik untuk mengontrol setiap hafalan bacaan siswanya. Maka menghafal kata demi kata dengan melakukan prdiksi-prediksi dalam bacaan akan memberikan kontribusi maksimal terhadap peningkatan kemampuan siswa dalam memahami bacaan.

Dalam mengasah kemampuan memprediksi bacaan siswa dapat dilakukan dengan berbagai cara, salah satunya menggunakan big book, sebagai contoh, siswa diminta untuk menebak kata yang terdapat pada judul bacaan namun, sebelumnya beberapa kata yang terdapat pada judul ditutup, kemudian siswa diminta untuk memperhatikan gambar yang terdapat pada cover buku, lalu meminta mereka untuk menceritakan apa yang mereka perhatikan dengan merangsangnya menggunakan pertanyaan ADIKSIMBA atau sering disebut dengan $5 \mathrm{~W}+1 \mathrm{H}$.

Penggunaan media big book ini juga dapat digunakan siswa untuk belajar mandiri di rumah, selain bentuknya yang menarik yang disertai dengan ilustrasi gambar, juga diberikan warna-warna yang menarik perhatian siswa, sehingga siswa tertarik untuk membacanya. Melihat konteks tersebut adapun rumusan masalah dalam penelitian ini yaitu "bagaimana pengembangan media big book yang valid, praktis dan efektif terhadap peningkatan kemampuan memprediksi bacaan cerita di kelas III SD Muhammadiyah 28 Medan"? 


\section{METODE PENELITIAN}

Metode penelitian yang digunakan dalam penelitian ini mengadopsi penelitian brog and gall yaitu Research and Development ( R\&D) yang merupakan rangkaian proses mengembangkan suatu produk yang baru maupun penyempurnaan produk yang dapat dipertanggung jawabkan. ${ }^{12}$ Kegiatan penelitian dan pengembangan Research and Development ( R\&D) secara umum dapat disingkat menjadi 6 tahapan dengan ujicoba secara terbatas karena keterbatasan waktu dan biaya. Sugiyono. ${ }^{13}$ Populasi dalam penelitian ini adalah seluruh siswa kelas III SD Muhamadiyah 28 Medan, pengambilan sampel dilakukan menggunakan teknik purposive sampling, dengan mempertimbangkan daya nalar siswa dilihat dari nilai ujian harian siswa.maka ditentukan sampel yang digunakan berjumlah 24 siswa dari keseluruhan populasi berjumlah 48 siswa. Teknik pengumpulan data dalam

Penelitian ini menggunakan wawancara untuk memperoleh informasi awal, dan angket untuk mengetahui respon sampel dan proses yang terjadi pada saat sampel diberi perlakuan. Instrument yang digunakan juga berupa wawancara, lembar validasi yang digunakan untuk memvalidasi isi/materi, serta desain, sedangkan data dianalisis menggunakan teknik analisis data statistic deskriptif dengan bantuan SPSS versi 21.

Produk yang akan dikembangkan dalam penelitian ini adalah media big book. Media big book merupakan media berbentuk gambar dan tulisan dalam ukruan besar.

Fungsi media ini adalah membantu meningkatkan kemampuan memprediksi bacaan cerita peserta didik pada materi perubahan wujud benda untuk peserta didik kelas III. Adapun langkah-langkah merancang produk adalah sebagai berikut:

\footnotetext{
${ }^{12}$ Salim dan Haidir, Penelitian Pendidikan, (Jakarta: Kencana,2019), hlm.58

${ }^{13}$ Sugiyono, Metode Penelitian dan Pengembangan, (Bandung: Alfabeta,2017) ,hlm
} 
1. Menyiapkan kertas berukuran A3/buku gambar A3.

2. Menyiapkan pensil, penggaris, penghapus, pensil warna dan twin pen.

3. Menentukan topik cerita yang berhubungan dengan materi perubahan wujud benda.

4. Menggambar ilustrasi cerita.

5. Membuat tulisan isi cerita di halaman sebelah gambar.

6. Menghias media big book.

Adapun tahapan pengembangannya sebagai berikut:

\section{Tahap Pengembangan Produk}

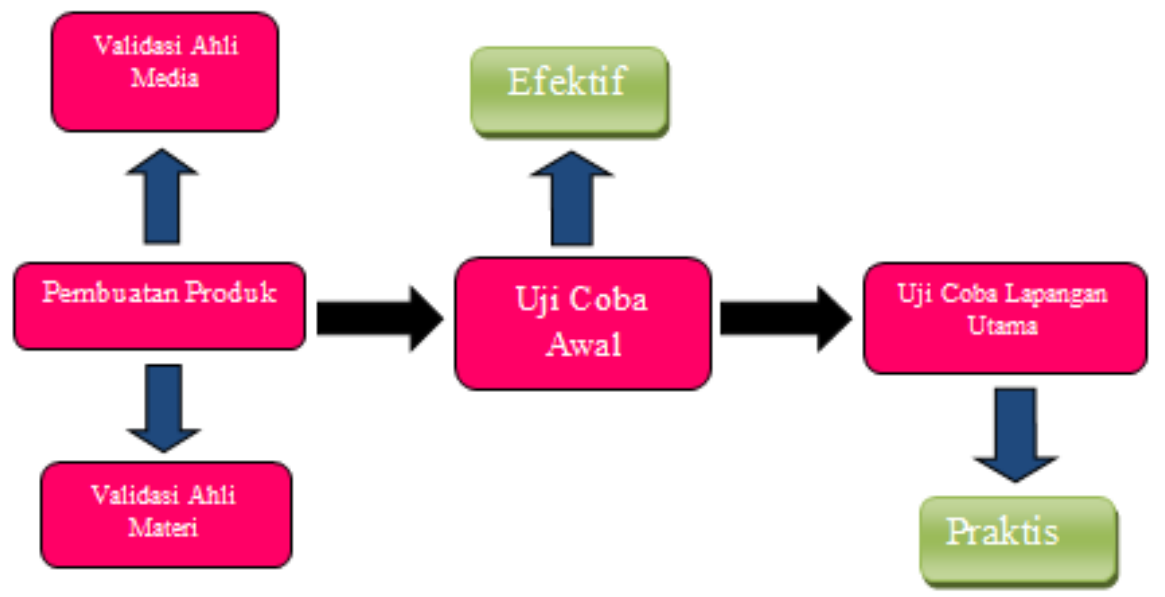

Dari bagan tersebut terlihat bahwa pada uji coba awal peneliti memvalidasikan produk kepada ahli isi/materi dan ahli media, untuk diperoleh data hasil validasi kemudian diadakan revisi produk jika hasil validasi berada pada kategori tidak valid. Produk yang telah direvisi kemudian diujicoba lapangan awal untuk mengetahui keefektifan/efektivitas produk kemudian padauji coba lapangan utama dilakukan untuk mengetahui kepraktisan produk yang telah dibuat. 


\section{HASIL PENELITIAN DAN PEMBAHASAN}

\section{Deskripsi Data atas Jawaban Terhadap Rumusan Masalah}

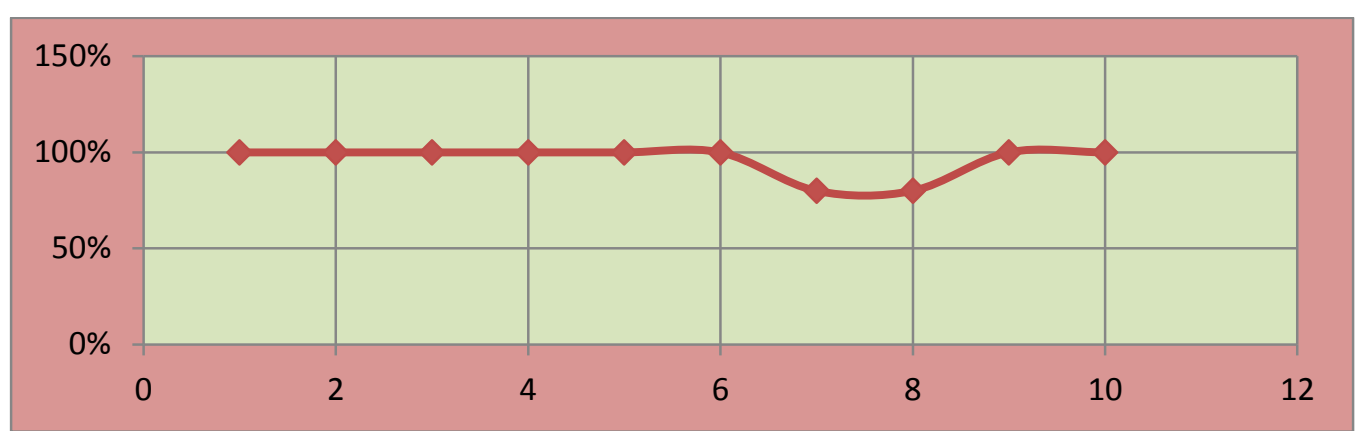

Gambar 4.1 Hasil Validasi isi/ Materi

Dari grafik di atas dapat diketahui bahwa pemerolehan skor pada setiap kriteria rata-rata memperoleh skor maksimal yaitu 100, dan 2 kriteria mendapat skor 80, dengan kata lain produk yang dikembangkan dapat digunakan.

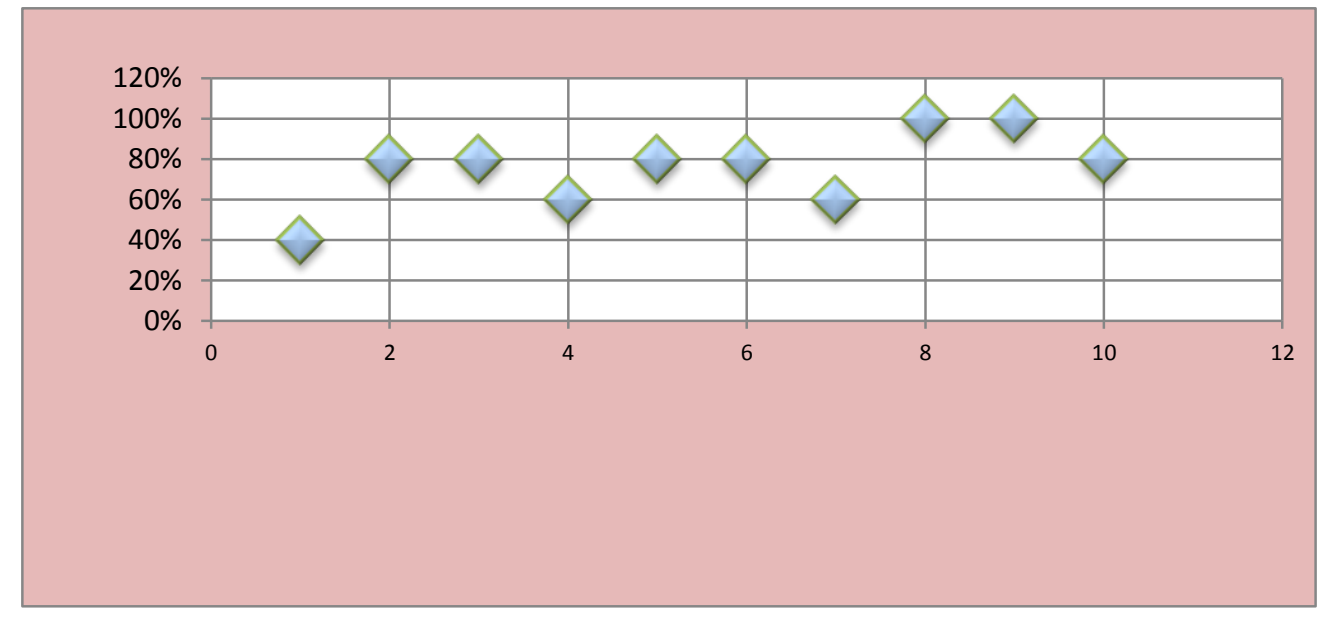

\section{Gambar 4.2 Hasil Validasi Ahli Media}

Dari grafik di atas dapat diketahui bahwa pemerolehan skor pada uji ahli desain produk memperoleh skor 40 untukkriteria satu, skor 60 untuk kriteria 4 dan 7 , lalu memperoleh skor 80 untuk kriteria 2,3,5,6,10, serta mendapat skor 100 untuk kriteria 8,9 dengan kata lain dari segi desain produk belum dapat digunkan dan memerlukan revisi. Setelah dilakukan revisi pada kriteria 1,4 dan 7 diperoleh hasil sebagai berikut: 


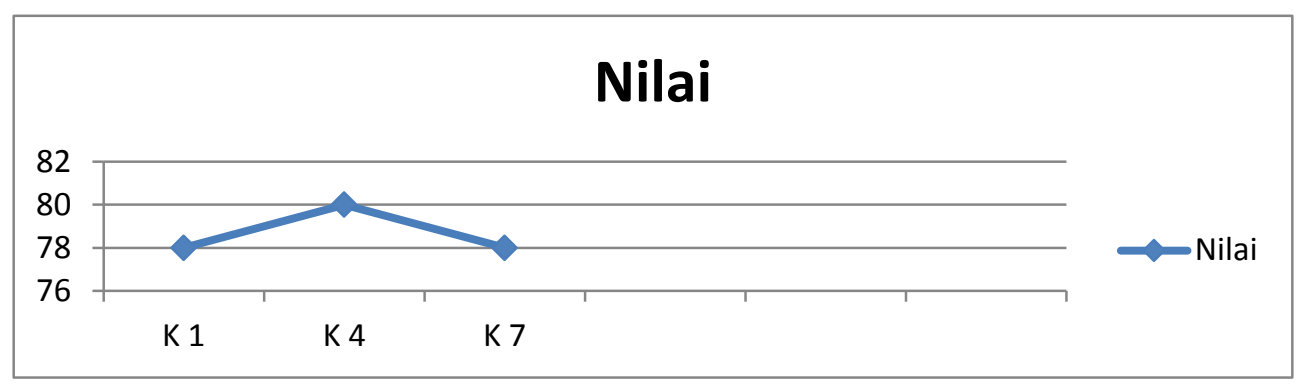

\section{Gambar 4.3 sil Revisi Validasi Uji Desain}

Dilihat pada table di atas untuk kriteria 1 setelah direvisi memperoleh skor 78 yang sebelumnya skrornya 40, begitu juga skor kriteria 4 memperoleh skor sesudah revisi 80 yang sebelumnya 60, dan skor 7 sesudah revisi skornya 78 yang sebelumnya 60. Melihat hasil yang diperoleh setelah revisi untuk Hasil Validasi ahli Desain maka dapat disimpulkan bahwa produk dapat digunakan untuk pengujian selanjutnya.Setelah produk dinyatakan dapat digunakan oleh ahli isi/materi, dan ahli desain, selanjutnya produk di Uji Cobalapangan, untuk menguji keparaktisan produk, adapun hasilnya sebagai berikut:

\begin{tabular}{|l|r|}
\hline \multicolumn{2}{|c|}{ Test Statistics $^{\text {a }}$} \\
\hline & \\
\hline$Z$ & Sesudah - Sebelum \\
\hline Asymp. Sig. (2-tailed) & $-3,846^{\circ}$ \\
\hline a. Wilcoxon Signed Ranks Test & 0,000120 \\
\hline b. Based on negative ranks. \\
\hline
\end{tabular}

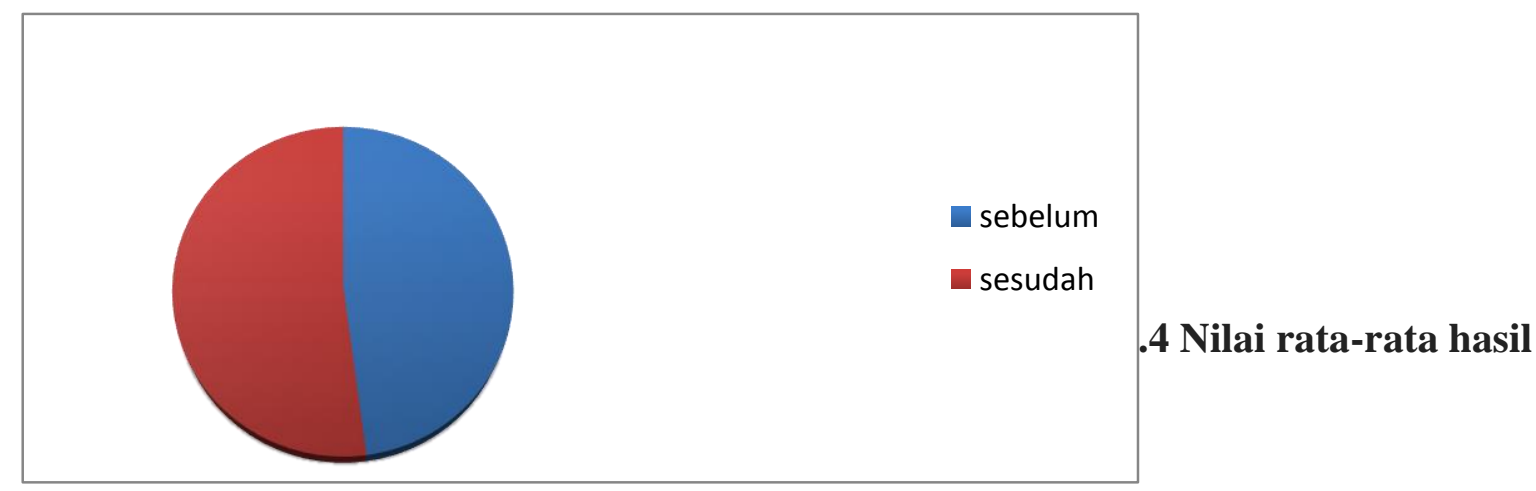




\section{Gambar 4.4 Nilai rata-rata hasil prediksi dan hasil sig. bacaan cerita siswa}

\section{sebelum menggunakan big book dan setelah menggunakan big book.}

Dari gambar di atas dapat diketahui bahwa persentase hasil prediksi bacaan siswa setelah menggunakan big book lebih besar dari pada sebelum menggunakan big book. Dengan nilai sebelum menggunakan big book 60,54 sedangkan setelah menggunakan big book naik menjadi 84,33 dengan sig 0,000120. dengan data berdistribusi normal menggunakan uji Shapiro- Walk seperti di bawah ini:

\begin{tabular}{|c|c|c|c|c|c|c|}
\hline \multicolumn{7}{|c|}{ Tests of Normality } \\
\hline & \multicolumn{3}{|c|}{ Kolmogorov-Smirnov } & \multicolumn{3}{|c|}{ Shapiro-Wilk } \\
\hline & $\begin{array}{c}\text { Statisti } \\
\mathrm{C}\end{array}$ & Df & Sig. & $\begin{array}{c}\text { Statisti } \\
c\end{array}$ & Df & Sig. \\
\hline $\begin{array}{l}\text { Sebelu } \\
\mathrm{m}\end{array}$ &, 114 & 24 &, $200^{\circ}$ &, 969 & 24 & 0,650 \\
\hline $\begin{array}{l}\text { Sesud } \\
\text { ah }\end{array}$ &, 176 & 24 &, 052 & 833 & 24 & 0,061 \\
\hline \multicolumn{7}{|c|}{ *. This is a lower bound of the true significance. } \\
\hline \multicolumn{7}{|c|}{ a. Lilliefors Significance Correction } \\
\hline
\end{tabular}

Berdasarkan data di atas dapat disimpulkan bahwa produk bigg book ini praktis digunakan oleh sampel untuk meningkatkan prediksi bacaan cerita siswa.kemudian untuk menguji keefektifan produk peneliti menggunakan instrument berbentuk angket untuk melihat respon padasampel dan respon guru, adapun hasilnya seperti di bawah ini:

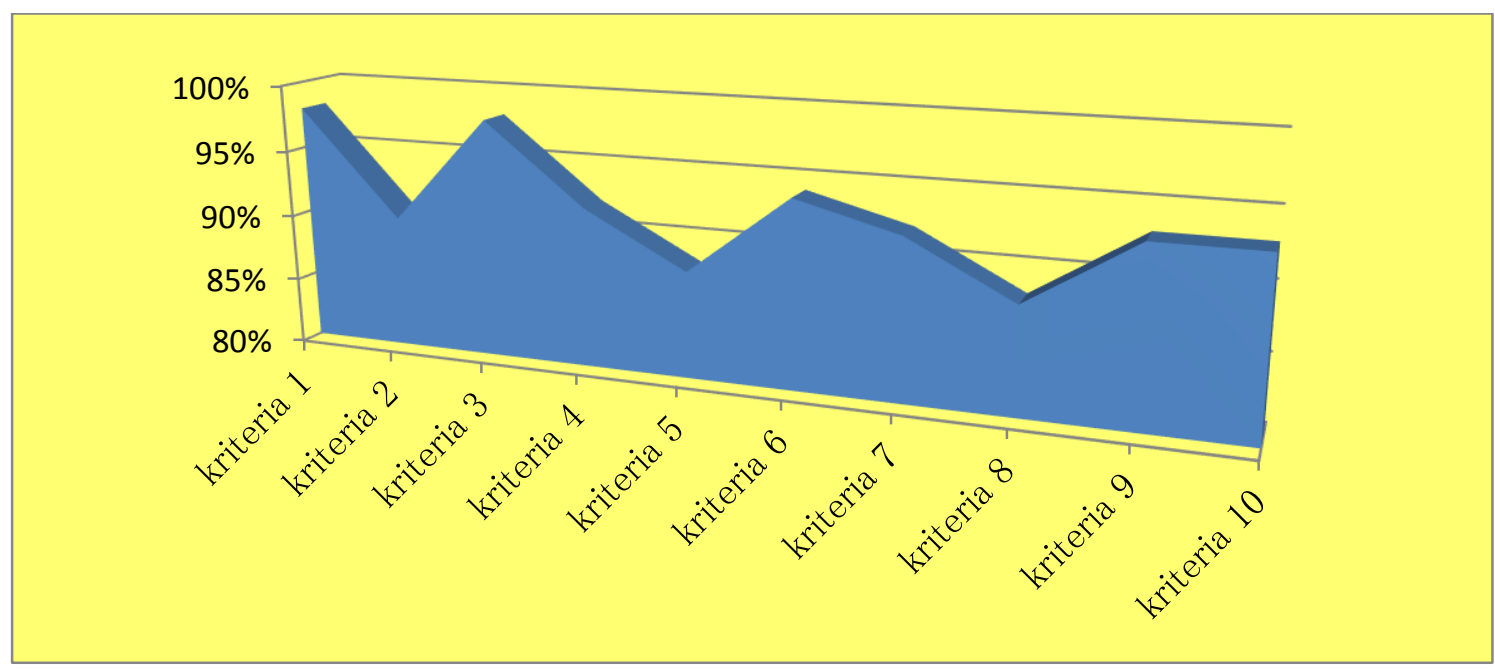




\section{Gambar 4.5 Grafik respon pada sampel}

Berdasarkan grafik di atas dapat diketahui bahwa respon yang diberikan sampel pada penggunaan big book sangat baik, yaitu rata-rata dengan skor diatas 82 untuk setiap kriteria. Selain itu adapun hasil respon penggunaan big book untuk meningkatkan prediksi bacaan cerita siswa yaitu:

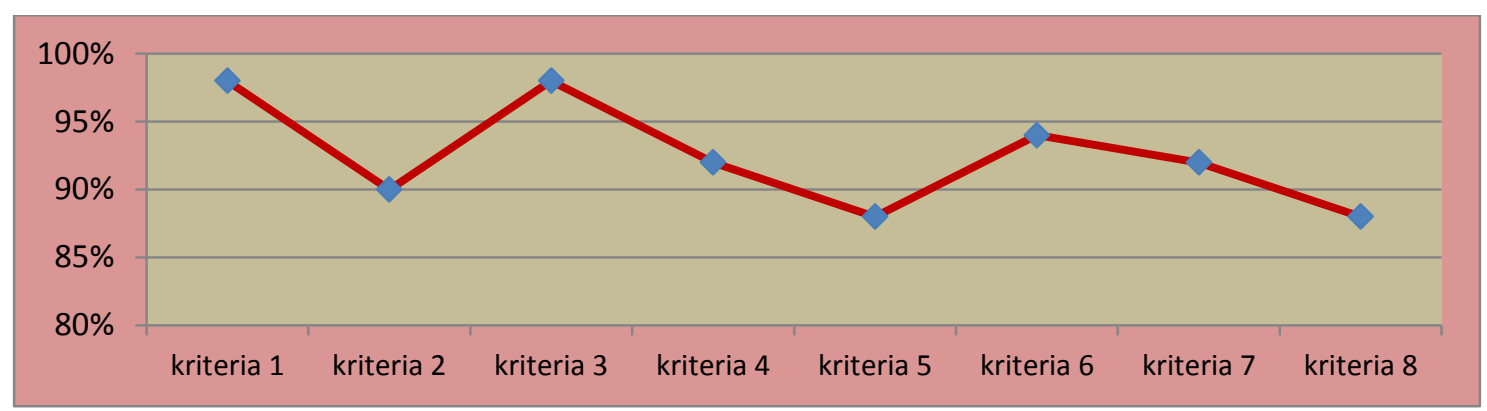

Berdasarkan pada grafik di atas dapat diketahui bahwa untuk 10 kriteria untuk indicator keefektifan penggunaan produk big book yang diberikan kepada guru dapat diketahui secara keseluruhan efektif dengan rata-rata skor yang diperoleh 87,5 .

\section{Deskripsi Data Terhadap Hipotesis dalam Penelitian.}

Dalam penelitian ini hipotesis diuji menggunakan uji Mann-Withney dengan mengambil taraf sig. 0.05. Adapun hipotesis yang akan diuji yaitu:

$\mathrm{H}_{0}$ : Pengembangan mediabig book tidak valid, praktis, dan efektif terhadap peningkatan kemampuan memprediksi bacaan cerita siswa kelas III SD Muhamadiyah 28 Medan.

$\mathrm{H}_{1}$ : Pengembangan mediabig book valid,praktis, dan efektif terhadap peningkatan kemampuan memprediksi bacaan cerita siswa kelas III SD Muhamadiyah 28 Medan. 
Hasil pengujian hipotesis menggunakan uji Mann-Whitney sebagai berikut:

\begin{tabular}{|l|c|}
\hline \multicolumn{2}{|c|}{ Test Statistics $^{\mathbf{a}}$} \\
\hline Mann-Whitney U & Nilai \\
\hline Wilcoxon W & 141,000 \\
\hline Z & 441,000 \\
\hline Asymp. Sig. (2-tailed) & $-3,046$ \\
\hline a. Grouping Variable: Kelompok &, 002 \\
\hline
\end{tabular}

Dari tabel tersebut, diperoleh bahwa $Z_{\text {hitung }}$ sebesar -3,046 dengan nilai Sig.0,002. Nilai signifikansi tersebut lebih kecil dari 0,05 yaitu $0,002<0,05$ sehingga berdasarkan kriteria pengambilan keputusan maka Ha diterima. Hal ini menunjukkan bahwa terdapat pengaruh media pembelajaran Big Book untuk meningkatkan kemampuan memprediksi bacaan cerita peserta didik.

\section{Deskripsi Produk Big Book}

Produk yang dikembangkan dari penelitian ini adalah media pembelajaran Big Book atau buku besar.Big Book memiliki gambar dan cerita dengan ukuran yang besar memenuhi kertas yang digunakan. Pada penelitian ini, peneliti membuat Big Book dengan deskripsi sebagai berikut:

a. Menggunakan buku gambar A3 yang berukuran panjang $42 \mathrm{~cm}$ dan lebar $29,7 \mathrm{~cm}$.

b. Media pembelajaran Big Book dibuat manual. Gambar pada Big Book merupakan hasil gambar tangan yang kemudian diberi warna dengan full colour untuk menarik perhatian peserta didik di tingkat Sekolah Dasar (SD). 
c. Pada halaman berikutnya ditulis cerita berdasarkan gambar yang ada, adapun tema cerita yang diangkat adalah materi perubahan wujud benda yang terdiri dari perubahan wujud benda mencair, menguap, menyublim, mengembun, dan membeku.

d. Sebagai finishing, untuk mempercantik tampilan Big Book, buku gambar disampul dengan kertas kado dan ditempelkan tulisan "Big Book".

Produk Big Book yang dihasilkan adalah sebagai berikut:

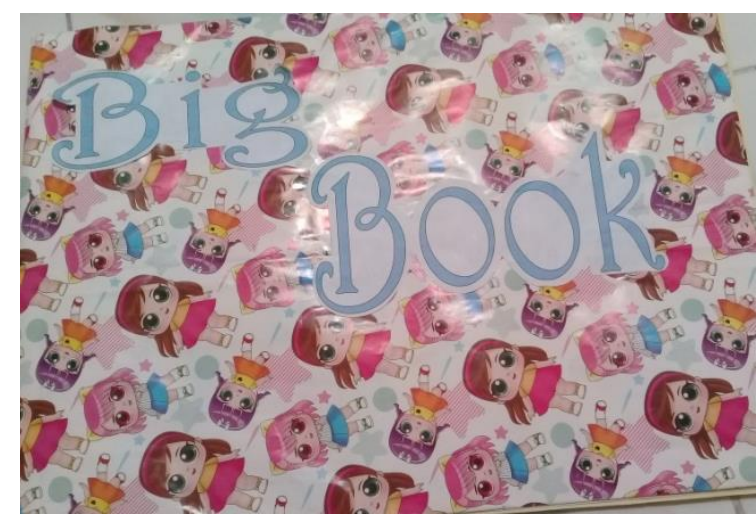

Sampul depan Big Book
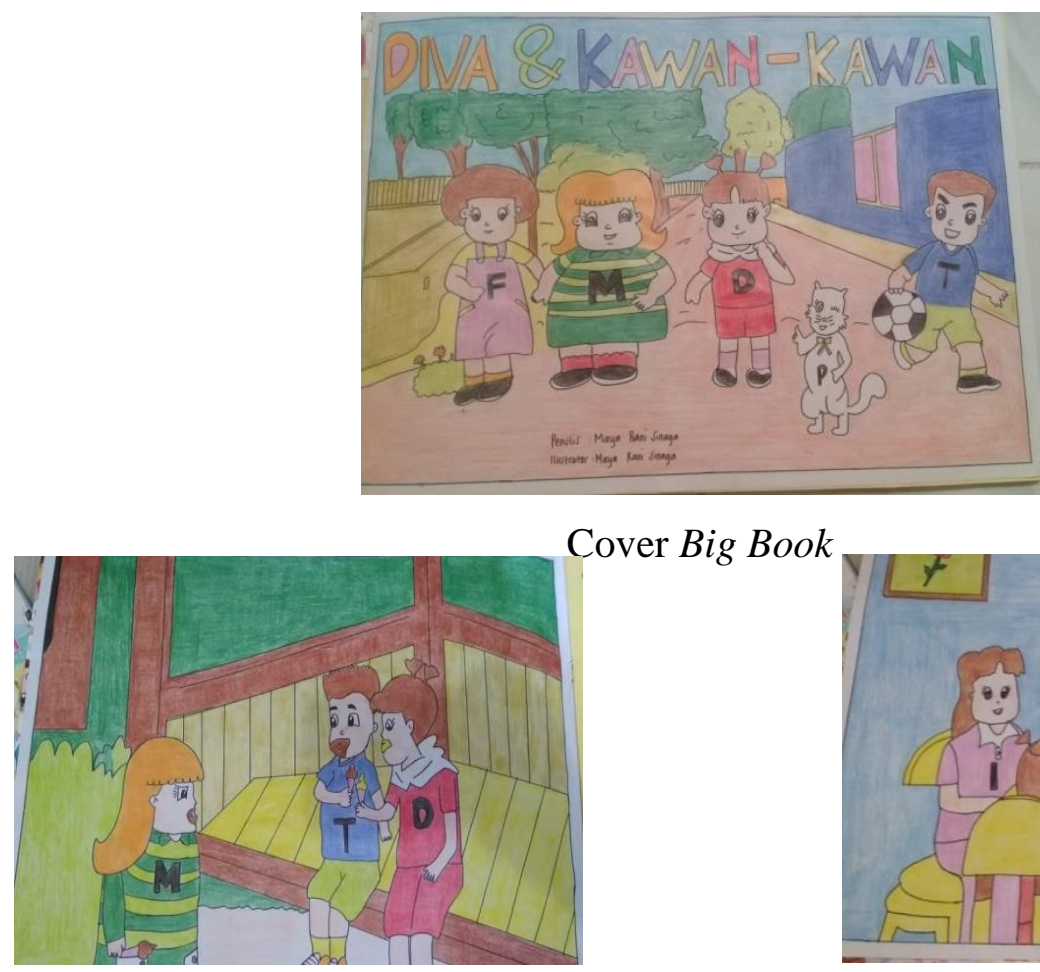

Cover Big Book

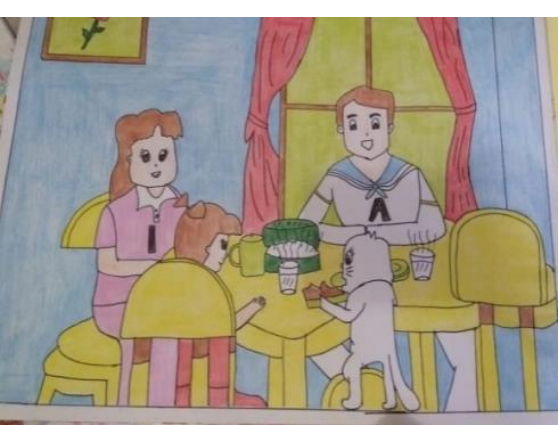

Vol. 2, No. 1, Juni 2020 
Gambar 1

(Perubahan Wujud Benda Mencair)

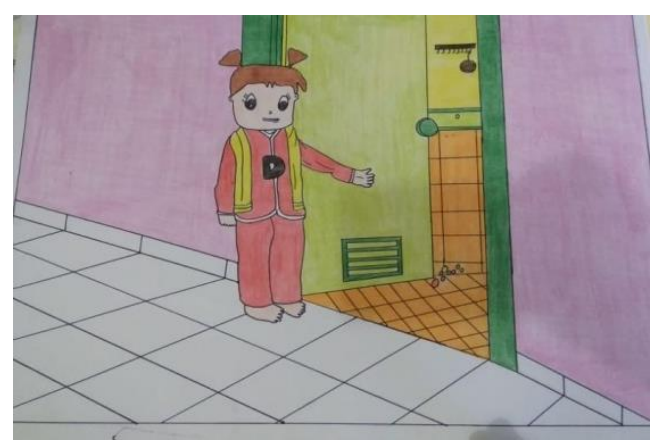

Gambar 3
Gambar 2

(Perubahan Wujud Benda Menguap)

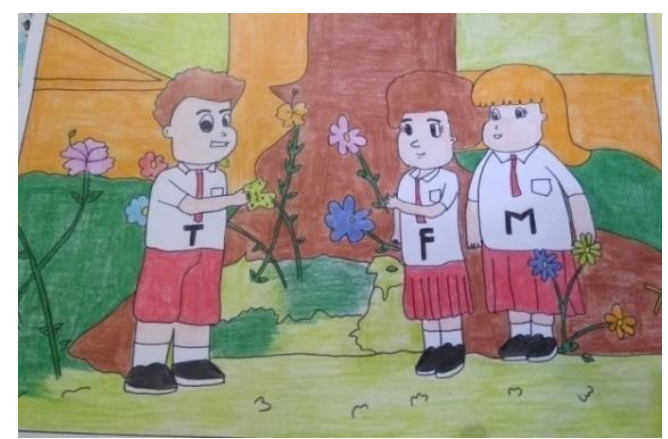

Gambar 4

(Perubahan Wujud Benda Menyublim) (Perubahan Wujud Benda Mengembun)

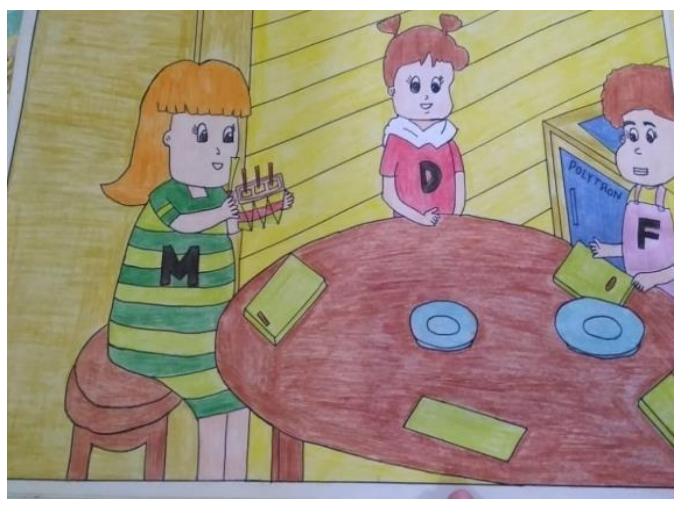

Gambar 5 (Perubahan Wujud Benda Membeku)

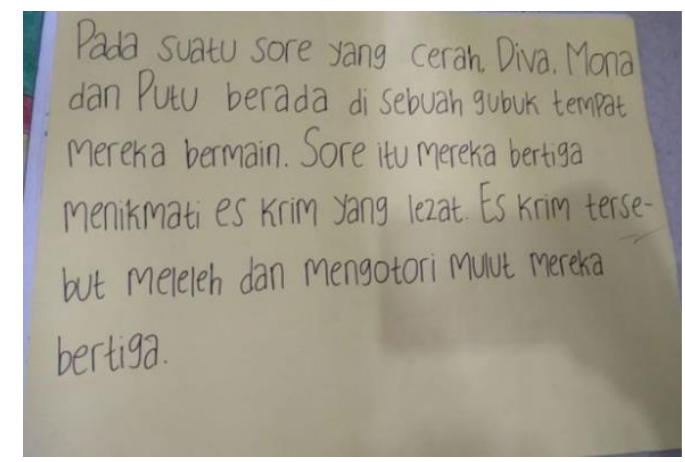




\section{Cerita 1}

(Perubahan Wujud Benda Mencair)

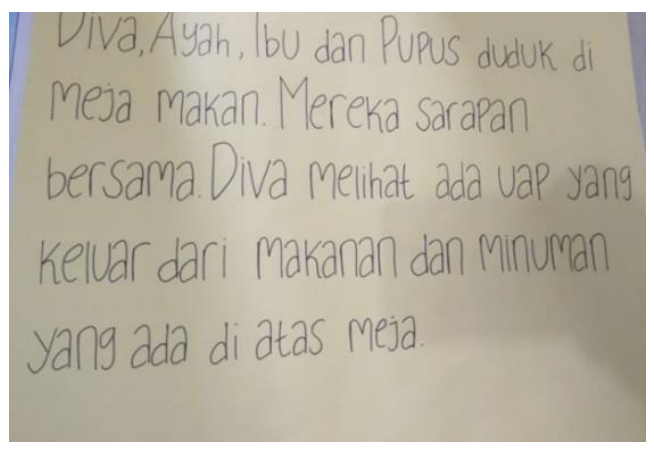

Cerita 2

(Perubahan Wujud Benda Menguap)

Menyublim)

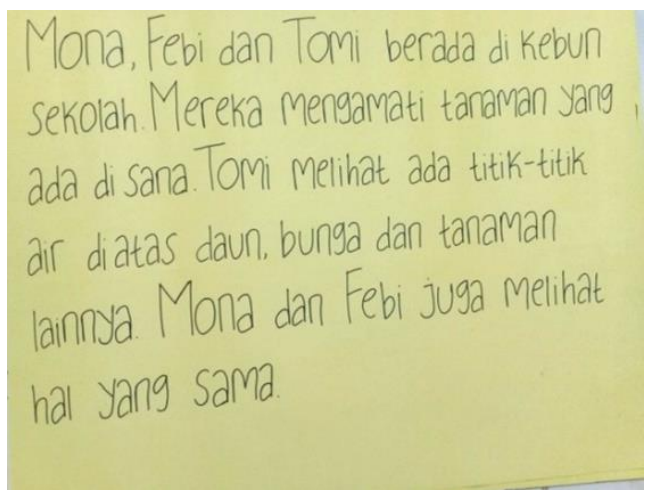

Cerita 4

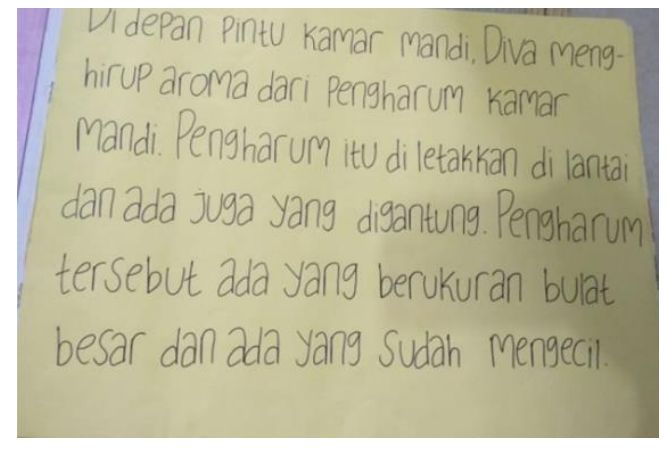

Cerita 3

(Perubahan Wujud Benda

(Perubahan Wujud Benda Mengembun) (Perubahan Wujud Benda Membeku) 


\section{KESIMPULAN}

Berdasarkan proses pengembangan media dan uji coba terhadap media pembelajaran Big Book, maka dapat disimpulkan sebagai berikut:

1) Pengembangan media Big Book yang sudah selesai kemudian divalidasi. Pada tahap validasi ahli isi/materi memperoleh skor $96 \%$ dengan kategori sangat valid, kemudian validasi ahli desain media pembelajaran memperoleh skor $62 \%$ dengan kategori cukup valid, setelah diadakan revisi validasi ahli desain media pembelajaran memperoleh skor $76 \%$ dengan kategori valid.

2) Media pembelajaran Big Book digunakan untuk uji coba lapangan. Setelah penggunaan media Big Book, untuk mengetahui tingkat kepraktisan media dilakukan denganpenyebaran angket kepada peserta didik dan guru. Respon dari peserta didik dianalisis dan memperoleh skor 93\% dalam kategori sangat praktis, sedangkan respon dari guru memperoleh skor $87,5 \%$ dalam kategori sangat praktis.

3) Untuk mengetahui keefektifan media pembelajaran Big Book terhadap kemampuan memprediksi bacaan cerita maka dilakukan dengan melakukan uji coba terhadap sampel sebelum dan sesudah penggunaan produk, kemudian dilakukan uji wilcoxon dan diperoleh nilai signifikansi $<0,05$ sehingga terdapat perbedaan nilai sebelum dan sesudah penggunaan produk.

4) Uji hipotesis dengan menggunakan uji Mann-Whitney dengan taraf signifikansi $\propto=0,05$. Dari pengujian hipotesis diperoleh nilai signifikansi lebih kecil dari 0,05 yaitu $0,002<0,05$ sehingga berdasarkan kriteria pengambilan keputusan maka $\mathrm{H}_{\mathrm{a}}$ diterima. Hal ini menunjukkan bahwa 
BADA'A: Jurnal Ilmiah Pendidikan Dasar

Vol. 2, No. 1, Juni 2020, Hal 108-124

E-ISSN: 2714-

7711

terdapat pengaruh media pembelajaran Big Book untuk meningkatkan kemampuan memprediksi bacaan cerita peserta didik 


\section{DAFTAR PUSTAKA}

Ivonne Hafidlatil Kiromi dan Puji Yanti Fauziah, (2016), Pengembangan Media Big Book untuk Pembentukan Karakter Anak Usia Dini, Yogyakarta: Jurnal Pendidikan dan Pemberdayaan Masyarakat,Vol.3, No.1

Asep Kustiawan,Pengembangan Media Pembelajaran Anak Usia Dini,Malang: Gunung Samudera.2016

Lefudin. Belajar \& Pembelajaran,Yogyakarta: Deepublish.2017

H M Syakur, Pembelajaran Tematik Untuk Kelas Rendah, Kudus: Maseifa Jendela Ilmu.2016

Jalinus,Nizwardi dan Ambiyar. Media dan Sumber Pembelajaran, Jakarta: Kencana. 2016

Junaida dkk. Pembelajaran Bahasa Indonesia di MI/SD,Medan: Perdana Publishing.2018

Djiwandono,Sri Esti Wuryani.2004.Psikologi Pendidikan.Jakarta: GrasindoHidayah Nurul.2016.Pembelajaran Bahasa Indonesia di Perguruan Tinggi, Yogyakarta: Garudhawaca

Solehuddin dkk. Pembaharuan Pendidikan TK,Jakarta: Universitas Terbuka.2009

Syelviana,Nisfhi dan Sri Hariani.2019.Pengembangan Media Big Book dalam Pembelajaran Membaca Permulaan di Kelas I Sekolah Dasar,Surabaya: Jurnal PGSD Vol.07,No.01, diakses pada 16 Januari 2020.

Gunanti Setiyaningsih dan Amir Syamsudin, (2019), Pengembangan Media Big BookUntuk Meningkatkan Kemampuan Literasi Anak Usia 5-6 Tahun, Yogyakarta: Jurnal Scholaria, Vol.9, No.1

Irma Rahmawati, (2017), Pengembangan Media Big Book berbasis Keterampilan Membaca Peserta didik Kelas 1 Sekolah Dasar, Semarang: Artikel Seminar Nasional PGSD

Salim dan Haidir, Penelitian Pendidikan, Jakarta: Kencana,2019

Sugiyono. Metode Penelitian dan Pengembangan.Bandung: Alfabeta. 2017 